\title{
PENERAPAN MODEL PEMBELAJARAN BERBASIS MASALAH UNTUK MENINGKATKAN KETERAMPILAN BERPIKIR KRITIS SISWA SMA NEGERI 2 METRO
}

\author{
Ade Gunawan \\ Pendidikan Biologi FKIP Universitas Muhammadiyah Metro \\ E-mail : aa_gun8987@yahoo.com
}

\begin{abstract}
The research was to incrase of students' critical thinking skills. The subject of this study were SMAN 2 Metro grade X4 class numbering 30 student in the second semester of the academic 2011/2012. And the object of his research is the critical thinking skills. The results showed that the implementation of problem-based learning model on Biology learning, can increase students' critical thinking skills. Increase critical thinking skills is almost all indicators, such as the ability of clarification, argumentation skills, induction skills, deduction skills, and ability to perform and execute. Increase critical thinking skills that students can be seen from the increase in the average value of each point about the cycle I and cycle II. The success of critical thinking can also be seen from the increase in the thoroughness of learning, that is equal to 6 students in cycle I to cycle II is 24 students. The means the percentage of students who achieve greater value equal to 72 also increased, from $20 \%$ in cycle I to $80 \%$ in cycle II.
\end{abstract}

Kata Kunci: Pembelajaran Berbasis Masalah, Keterampilan Berpikir Kritis

\begin{abstract}
Mata pelajaran biologi pada sekolah menengah atas (SMA) diajarkan untuk membekali peserta didik pengetahuan, pemahaman, dan sejumlah kemampuan untuk memasuki jenjang pendidikan yang lebih tinggi serta mengembangkan ilmu dan teknologi. Untuk mencapai tujuan tersebut, maka diterapkan berbagai pendekatan, antara lain pendekatan induktif dalam bentuk proses inkuiri ilmiah pada tataran inkuiri terbuka. Proses inkuiri ilmiah bertujuan menumbuhkan kemampuan berpikir, bekerja dan bersikap ilmiah, serta berkomunikasi ilmiah sebagai salah satu aspek penting kecakapan hidup. Oleh karena itu, pembelajaran Biologi menekankan pada pemberian
\end{abstract}

pengalaman belajar secara langsung melalui penggunaan dan pengembangan keterampilan proses dan sikap ilmiah (BSNP, 2006).

Namun kenyataan di lapangan menunjukkan bahwa pembelajaran Biologi yang dilakukan lebih dominan kepada aspek pengetahuan dan pemahaman konsep. Akibatnya, kemampuan berpikir, bekerja ilmiah, dan kemampuan memecahkan masalah yang dihadapi dalam kehidupan nyata sehari-hari di kalangan para siswa tidak berkembang sesuai dengan harapan. Berpikir kritis adalah kemampuan memberi alasan secara terorganisasi dan mengevaluasi kualitas suatu alasan secara sistematis. Berpikir kritis dalam pembelajaran biologi sangat besar 
peranannya dalam meningkatkan proses, hasil belajar, dan bekal dimasa depan. Perkembangan kemampuan penalaran formal sangat penting bagi perolehan penguasaan konsep, karena pengetahuan konseptual merupakan akibat atau hasil dari suatu proses konstruktif, dan kemampuan penalaran tersebut adalah alat yang diperlukan pada proses itu.

Menurut Muhfahroyin (2009) berpikir kritis adalah proses yang melibatkan operasi mental seperti induksi, deduksi, klasifikasi, dan penalaran. Kunci berpikir kritis adalah mengembangkan

pendekatan impersonal yang memperhatikan argumentasi dan fakta sejalan dengan pandangan, pendapat dan perasaan personal. Ennis dalam Costa (1985), menyebutkan ada lima aspek berpikir kritis, yaitu a) memberi penjelasan dasar (klarifikasi), b) membangun keterampilan dasar, c) menyimpulkan, d) memberi penjelasan lanjut, dan e) mengatur strategi dan taktik. Lebih lanjut Arnyana (2004), mengemukakan terdapat enam variabel kemampuan berpikir kritis yang perlu dicermati pada siswa SMA, yaitu 1) kemampuan merumuskan masalah, 2) kemampuan memberikan argumentasi, kemampuan melakukan deduksi, 4) kemampuan melakukan induksi, 5) kemampuan melakukan evaluasi, dan 6) kemampuan memutuskan dan melaksanakan. Sedangkan Hassoubah (2007), menyebutkan bahwa keterampilan berpikir kritis adalah keterampilan untuk 1) menentukan kredibilitas suatu sumber, 2) membedakan antara yang relevan dari yang tidak relevan, 3) membedakan fakta dari penilaian, 4) mengidentifikasi dan mengevaluasi asumsi yang tidak terucapkan, 5) mengidentifikasi bias yang ada, 6) mengidentifikasi sudut pandang, dan 7) mengevaluasi bukti yang ditawarkan untuk mendukung pengakuan. Berdasarkan hal tersebut di atas, berpikir kritis adalah keterampilan berpikir tingkat tinggi yang berpotensi meningkatkan daya analitis kritis siswa. Peningkatan daya analitis kritis siswa sangat berkaitan dengan peningkatan kemampuan intelektual siswa. Oleh karena itu, menumbuhkembangkan keterampilan berpikir kritis siswa dalam pembelajaran merupakan upaya untuk meningkatkan hasil belajar siswa. Berdasarkan hal tersebut di atas, berpikir kritis adalah keterampilan berpikir tingkat tinggi yang berpotensi meningkatkan daya analitis kritis siswa dan memperkuat pemahaman konsep siswa dipihak lain.

Kenyataan di lapangan menunjukkan bahwa banyak siswa yang menyukai pelajaran biologi namun sulit untuk memahami sehingga proses pembelajaran hanya sebatas pengetahuan.Kesulitan siswa mempelajari Biologi disebabkan oleh materi ilmu Biologi yang sebagian bersifat kasat mata dan sebagian aspek lainnya bersifat abstrak. Kesulitan ini berpengaruh langsung maupun tidak langsung terhadap minat dan motivasi siswa untuk menggali lebih dalam apa yang ada dari pembelajaran biologi. Akibatnya, guru mengalami banyak kesulitan untuk memusatkan perhatian siswa dalam proses pembelajaran.

Hasil belajar siswa pada mata pelajaran Biologi, di SMA Negeri 2 Metro dapat dilihat dari hasil ulangan harian pokok bahasan virus tahun pelajaran 2011/2012, siswa yang tuntas atau memperoleh nilai $\geq 72$ sebanyak 16 siswa atau $53,4 \%$ sedangkan untuk kategori tidak tuntas yaitu yang memperoleh nilai $<72$ terdapat $46,6 \%$. Namun hasil ini masih relatif rendah jika dilihat dari indikator yang 
ditetapkan sekolah, sedangkan ketuntasan hasil belajar siswa yang diharapkan adalah mencapai $75 \%$ yang disepakati sekolah dengan kriteria ketuntasan minimal (KKM) 72. Terdapat beberapa faktor yang mempengaruhi hasil belajar ini, diantaranya kualitas masukan dan proses kegiatan belajar mengajar. Berkaitan dengan hal tersebut, maka perlu dirancang pembelajaran yang dapat meningkatkan keterlibatan siswa dalam proses pembelajaran biologi, salah satunya dengan model pembelajaran berbasis masalah (Problem Based Learning) sehingga dengan model ini tersebut mampu menumbuhkembangkan keterampilan berpikir kritis siswa dalam rangka peningkatan hasil belajar.

Beberapa hal yang perlu diperhatikan pada pembelajaran Biologi yang sesuai dengan karakteristik (ciri) ilmu Biologi, yaitu 1) pembelajaran Biologi harus menarik, 2) mengikuti hirarki peningkatan konsep dengan contoh sehari-hari agar persyaratan prior knowledge pada konstruktivisme dipenuhi, 3) dapat digunakan untuk memahami beritaberita mutakhir tentang iptek dengan Biologi dalam media masa, 4) melibatkan siswa secara aktif selama pembelajaran sehingga menyeimbangkan antara proses dan content, 5) merangsang rasa ingin tahu untuk mencari dan belajar sendiri, 6) menekankan pada pengertian dan bukan ingatan atau hafalan, 7) harus terpadu, seperti Biokimia, Biogeokimia, dan Biometri, 8) materi ajar Biologi harus lengkap, ekstensif dan menyeluruh, dan 9) bentuk asesmen disesuaikan dengan bahan ajar dan lebih berorientasi pada pemecahan masalah terpadau.

Pembelajaran yang kreatif dan inovatif tersebut hendaknya sinergis dengan paradigma baru dalam dunia pendidikan yang berorientasi pencapaian kompetensi. Dalam hal ini, tanggung jawab belajar berada pada diri siswa, tetapi guru tetap bertanggung jawab untuk menciptakan situasi yang mendorong prakarsa, motivasi dan tanggung jawab siswa untuk belajar sepanjang hayat (Depdiknas, 2002). Oleh karena itu peranan guru lebih bertindak sebagai mediator, fasilitator, dan motivator. Pembelajaran yang dirancang tersebut disesuaikan dengan situasi dan kondisi sekolahnya, sehingga pembelajaran menjadi bermakna dan kontekstual, artinya menyentuh langsung dalam kehidupan nyata sehari-hari. Pembelajaran berbasis masalah adalah alternatif model pembelajaran inovatif yang dikembangkan berlandaskan paradigma konstruktivistik. Esensi dari model pembelajaran tersebut adalah adanya reorientasi pembelajaran dari semula berpusat pada pengajar menjadi berpusat pada pebelajar. Model pembelajaran berbasis masalah memberikan peluang pemberdayaan potensi berpikir pebelajar dalam aktivitas-aktivitas pemecahan masalah dan pengambilan keputusan dalam konteks kehidupan dunia nyata yang kompleks.

Model pembelajaran berbasis masalah (problem based learning), dilaksanakan dengan lima langkah (fase) pembelajaran, yaitu: (1) mengarahkan siswa pada masalah (orient students to the problem) (2) mengorganisasi siswa dalam belajar (organize students for study), (3) membimbing secara individual maupun kelompok melakukan penyelidikan (assist independent and group investigation), (4) mengembangkan dan menyajikan hasil karya (develop and present artifacts and exhibits), dan (5) menganalisis dan mengevaluasi proses 
pemecahan masalah (analyze and evaluate the problem-solving process) (Arends, 2004: 406). Untuk mendukung efektivitas pembelajaran berbasis masalah, maka dapat menggunakan berbagai media dan sumber belajar.

Berdasarkan hal tersebut di atas, maka melalui penerapan model pembelajaran Biologi berbasis masalah, berpotensi meningkatkan aktivitas dan kreativitas siswa dalam pembelajaran. Melalui penerapan model pembelajaran ini, aktivitas dalam pembelajaran lebih didominasi oleh kegiatan siswa (student center). Sedangkan guru cendrung sebagai fasilitator, mediator, motivator, konsultan, dan pendengar yang empati. Dalam hal ini, siswa belajar mulai dari mencari pengetahuan yang relevan, merancang penyelidikan atau percobaan, mengamati, mengumpulkan dan menganalisis data hasil penelitian, memecahkan masalah yang ditemukan dalam kehidupan sehari-hari, dan mengkomunikasikan pengetahuan yang diperolehnya. Akibatnya, keterampilan berpikir kritis siswa dalam pembelajaran Biologi dapat ditingkatkan.

Berdasarkan latar belakang dan identifikasi masalah tersebut maka dapat dirumuskan masalah sebagai berikut Apakah Implementasi Model Pembelajaran Berbasis Masalah dapat meningkatkan keterampilan berpikir kritis siswa kelas $\mathrm{X}_{4}$ SMA Negeri 2 Metro pada mata pelajaran Biologi?. Penelitian ini bertujuan untuk Meningkatkan keterampilan berpikir kritis siswa pada pembelajaran Biologi melalui implementasi model pembelajaran berbasis masalah. Manfaat yang diharapkan dari penelitian ini antara lain: 1) Memberikan informasi kepada guru sains pada umumnya dan guru Biologi khususnya, mengenai model pembelajaran Biologi berbasis masalah, sehingga dapat diterapkan sesuai dengan situasi dan kondisi di sekolahnya; 2) Memberikan sumbangan pemikiran tentang implementasi model pembelajaran berbasis masalah, sehingga dapat diimplementasikan atau dikembangkan dalam KBM dalam rangka meningkatkan kualitias proses dan hasil belajar; dan 3) Memberikan kontribusi yang positif terhadap perkembangan kreativitas pembelajaran Biologi dan dapat dijadikan acuan bagi pelaksanaan penelitian-penelitian yang relevan.

\section{METODE}

Penelitian ini merupakan penelitian tindakan kelas yang dilaksanakan pada semester genap tahun pelajaran 2011/2012. Penelitian ini dilaksanakan untuk standar kompetensi, yaitu memahami manfaat keanekaragaman hayati. Sedangkan kompetensi dasar yang dijadikan kajian penelitian, yaitu 1) mendeskripsikan konsep keanekaragaman gen, jenis, ekosistem melalui pengamatan dan 2) mengkomunikasikan keanekaragaman hayati indonesia, dan usaha pelestarian serta pemanfaatan sumber daya alam. Penelitian tindakan kelas ini dilaksanakan dalam dua siklus, dan masing-masing siklus terdiri dari empat tahapan, yaitu 1) perencanaan, 2) pelaksanaan tindakan, 3) observasi dan evaluasi tindakan, dan 4) refleksi. Siklus I dilaksanakan materi pokok tentang keanekaragam hayati, sedangkan siklus II diterapkan pada materi pokok usaha pelestarian dan konservasi keanekaragaman hayati indonesia. Untuk setiap siklus dirancang dalam 6 Jam pelajaran (2 kali tatap muka). Penelitian tindakan kelas ini dilaksanakan di bulan Februari 2012. 
Penelitian tindakan kelas ini dilakukan di SMA Negeri 2 Metro, Lampung pada semester genap tahun pelajaran 2011/2012. Subjek penelitiannya adalah siswa kelas $\mathrm{X}_{4}$ yang berjumlah 30 orang dengan rincian laki-laki 11 orang dan perempuan 19 orang. Sedangkan objek penelitiannya adalah keterampilan berpikir kritis siswa.

Pada tahap perencanaan peneliti melakukan langkah-langkah 1) mengkaji materi pokok, mempersiapkan silabus, dan rencana pelaksanaan pembelajaran, dan lembar kegiatan siswa, 2) mempersiapkan dan mengkaji format-format observasi dan evaluasi yang terdiri dari soal tes akhir pembelajaran, dan lembar observasi, mengkaji indikator untuk menentukan keberhasilan tindakan yang dilaksanakan, seperti rubrik penilaian keterampilan berpikir kritis.

Pelaksanaan tindakan pada prinsipnya merupakan realisasi dari suatu tindakan yang sudah direncanakan. Pada siklus I, materi pokok yang dikaji adalah keanekaragaman hayati yang dilaksanakan untuk dua kali tatap muka (6 x 45 menit). Sedangkan pada siklus II untuk materi pokok usaha pelestarian dan konservasi keanekaragaman hayati indonesia yang dilaksanakan untuk dua kali tatap muka (6 x 45 menit). Adapun langkah-langkah pelaksanaan tindakan, sebagai berikut: 1) Sebelum pembelajaran dimulai, maka dilaksanakan tanya jawab dengan siswa terhadap materi yang akan dibahas untuk mengetahui pengetahuan awal siswa terhadap bahan kajian yang akan dibahas, 2) Pembelajaran dilakukan dengan langkah-langkah pembelajaran berbasis masalah, yaitu a) mengorientasi siswa pada masalah, b) mengorganisasi siswa untuk belajar, c) membimbing penyelidikan individu maupun kelompok, d) mengembangkan dan menyajikan hasil karya, dan e) menganalisis dan mengevaluasi proses pemecahan masalah.

Selama

pembelajaran berlangsung, peneliti melakukan observasi terhadap strategi pembelajaran yang diterapkan dan melakukan perekaman terhadap proses belajar mengajar yang berlangsung. Variabel yang diamati sesuai dengan objek penelitian, yaitu tes dilakukan terhadap keterampilan berpikir kritis yang berupa peningkatan rata-rata hasil belajar diakhir setiap siklus.

Berdasarkan observasi dan evaluasi pada siklus I, peneliti mengadakan refleksi untuk melihat seberapa besar keberhasilan dan kegagalan dalam penerapan model pembelajaran yang dirancang. Refleksi dilakukan terhadap pencapaian keterampilan berpikir kritis siswa dan mencari faktor-faktor penyebab ketidakberhasilan tindakan serta mencari solusi terhadap permasalahan tersebut, serta upaya yang perlu dilakukan untuk meningkatkannya. Pencermatan yang dilakukan pada penerapan siklus I dievaluasi dan diinterpretasi penyebabnya untuk selanjutnya digunakan sebagai acuan dalam melakukan pemantapan pada siklus II.

Instrumen yang digunakan dalam penelitian ini berupa tes. Tes yang digunakan berupates akhir pembelajaran yang disusun dalam bentuk soal uraian untuk mengetahui keterampilan berpikir kritis siswa. Tes keterampilan berpikir kritis meliputi keterampilan untuk melakukan klarifikasi, memberikan argumentasi, melakukan induksi dan induksi, serta kemampuan melakukan dan melaksanakan.

Data yang dikumpulkan dalam penelitian ini adalah data kuantitatif 
berupa skor tes keterampilan berpikir kritis, skor tes akhir pembelajaran untuk siklus I dan siklus II. Untuk skor keterampilan berpikir kritis, dianalisis secara deskriptif dengan mencari nilai rata-rata tiap butir soal, dan ketuntasan belajar siswa. Kreteria keberhasilan peningkatan kualitas pembelajaran biologi, ditinjau hasil belajar siswa.

Data mengenai keterampilan berpikir kritis siswa dianalisis dengan cara mengkonversi nilai rata-rata setiap butir soal dan dimasukkan ke pedoman konversi nilai. Hal ini, untuk menentukan tingkat kualifikasi keterampilan berpikir kritis siswa. Pedoman konversi tersebut disajikan pada Tabel 1.

Tabel 1. Pedoman konversi

\begin{tabular}{|c|c|}
\hline Interval skor siswa & Keterangan \\
\hline$\leq 0$ & Sangat Rendah \\
\hline $5-9,9$ & Rendah \\
\hline $11-14,9$ & Sedang \\
\hline $15-19,9$ & Tinggi \\
\hline$\geq 20$ & Sangat Tinggi \\
\hline \multicolumn{2}{|c|}{ Ketuntasan siswa } \\
\hline
\end{tabular}

dinyatakan berhasil, jika ketuntasan belajar lebih besar atau sama dengan $75 \%$ dengan rata-rata nilai minimal 72 , sesuai dengan kriteria ketuntasan minimal yang ditetapkan di sekolah.

\section{HASIL}

Berdasarkan hasil tes evaluasi pada setiap akhir siklus I dan siklus II terdapat peningkatan keterampilan berpikir kritis siswa. Peningkatan tersebut ditunjukkan dengan peningkatan nilai rata-rata dari setiap butir soal yang memilki indikator seperti pada lampiran yang dapat dikerjakan oleh siswa serta peningkatan jumlah siswa yang mengalami ketuntasan dari evaluasi setiap siklus. Peningkatan hasil belajar tersebut dapat dilihat dalam Tabel 2.

\section{PEMBAHASAN}

Penerapan model pembelajaran berbasis masalah, mendapat respon yang postif dari siswa. Hal ini dapat dilihat dari keterampilan berpikir kritis mengalami peningkatan dari siklus I ke siklus II. Hal ini terjadi karena beberapa faktor, yaitu 1) siswa telah mempunyai pengalaman mengikuti pembelajaran dengan penerapan model pembelajaran berbasis masalah pada siklus I sehingga siswa sudah mampu beradaptasi dengan suasana pembelajaran, 2) adanya informasi mengenai penjelasan teknis serta kelemahan-kelemahan siswa dalam mengikuti pembelajaran oleh guru, menyebabkan siswa menerapkan strategi tertentu sebagai bentuk antisipasi, dan 3) penyampaian hasil belajar siswa baik secara individual maupun kelompok, menimbulkan rasa positif terhadap siswa, untuk berkompetisi dalam memperoleh hasil belajar yang lebih baik.

Keterampilan berpikir kritis yang ditunjukkan dari lima indikator, Dari tabel di atas dapat diketahui bahwa dari kelima indikator penilaian semuanya mengalami peningkatan, tiga indikator mencapai kategori tinggi dan dua indikator berkategori sedang. Pada kemampuan klarifikasi nilai rata-rata pada siklus I sebesar 9,5 nilai ini masih kategori rendah kemudian pada siklus II mengalami peningkatan dengan ratarata nilai 14 , nilai ini termasuk kategori sedang.

Selanjutnya pada kemampuan argumentasi nilai rata-rata siswa pada siklus I sebesar 9,3 dengan kategori rendah lalu naik pada siklus ke II dengan rata-rata nilai 16,16 , nili ini masuk dalam kategori tinggi. 
Tabel 2: Keterampilan Berpikir Kritis

\begin{tabular}{|c|l|c|c|c|c|}
\hline No & Indikator Penilaan & $\begin{array}{c}\text { Nilai rata-rata } \\
\text { Siklus I }\end{array}$ & Kategori & $\begin{array}{c}\text { Nilai rata-rata } \\
\text { Siklus II }\end{array}$ & Kategori \\
\hline 1 & Kemampuan Klarifikasi & 9,5 & Rendah & 14 & Sedang \\
\hline 2 & Kemampuan Argumentasi & 9,3 & Rendah & 16,16 & Tinggi \\
\hline 3 & Kemampuan Deduksi & 6,7 & Rendah & 13,3 & Sedang \\
\hline 4 & Kemampuan Induksi & 12,3 & Sedang & 16,16 & Tinggi \\
\hline 5 & $\begin{array}{l}\text { Kemampuan melakukan dan } \\
\text { melaksanakan }\end{array}$ & 19 & Tinggi & 17,5 & Tinggi \\
\hline
\end{tabular}

Pada kemampuan deduksi ratarata nilai pada siklus I sebesar 6,7 dengan kategori rendah mengalami peningkatan pada siklus II menjadi 13,3 dan masuk kedalam kategori sedang. Untuk kemampuan induksi pada siklus I nilai rata-rata sebesar 12,3 ini sudah berkategori sedang dan mengalami peningkatan pada siklus ke II menjadi 16,16 dengan kategori tinggi. Sedangkan kemampuan melakukan dan melaksanakan dengan rata-rata nilai 19 pada siklus I turun menjadi 17,5 pada siklus ke II. Namun penurunan tidak terjadi secara signifikan dan tetap pada kategori tinggi. Kondisi ini dapat dijadikan indicator, bahwa keterampilan berpikir kritis siswa dapat ditumbuhkembangkan dengan menerapkan model pembelajaran berbasis masalah pada mata pelajaran Biologi.

Hasil belajar dapat dikatakan pembelajaran sudah tuntas, ini dikarenakan dari 30 siswa yang mengikuti tes evaluasi hanya 6 siswa yang dinyatakan belum tuntas dan 24 siswa dinyatakan telah tuntas dengan nilai evaluasi di atas KKM yang ditetapkan sekolah. Sedangkan persentase ketuntasan mencapai $80 \%$ sudah melebihi indikator ketuntasan yang ditetapkan sekolah yaitu sebanyak75 \%.

Rendahnya pengetahuan awal siswa merupakan salah satu faktor yang menentukan keterampilan berpikir kritis siswa. Dengan demikian pengetahuan awal merupakan informasi sebagai bahan refleksi bagi guru untuk merencanakan strategi pembelajaran. Hal ini karena salah satu indikator kualitas proses pembelajaran adalah mengaitkan pengetahuan awal yang dimiliki siswa dengan bahan kajian yang akan dibahas (Depdiknas, 2002).

Akibat pengetahuan awal siswa yang masih rendah maka perlu direncanakan pembelajaran yang memberikan pengalaman konkrit kepada siswa. Salah satu diantaranya adalah dengan menerapakan model pembelajaran berbasis masalah. Masalah yang dipecahkan adalah masalah yang sering ditemukan dalam kehidupan nyata sehari-hari. Melalui penerapan model pembelajaran ini, siswa dapat mengikuti prosedur pembelajaran yang bermakna, dan mengandung langkah-langkah mengamati, melakukan, dan menginterpretasi data hasil pengamatan. Hal ini sesuai dengan yang disebutkan oleh Edgar Dale bahwa pengalaman belajar yang paling 
tinggi tingkatannya adalah pengalaman belajar konkret. Sedangkan yang paling rendah adalah pengalaman belajar abstrak (Ali, 2000).

Penerapan model pembelajaran berbasis masalah dalam pembelajaran Biologi, secara umum direspon positif oleh siswa. Hal ini terlihat dari kesungguhan dan kehadiran siswa mengikuti pembelajaran. Penerapan model pembelajaran berbasis masalah mampu meningkatkan motivasi dan minat siswa untuk belajar lebih baik. Ini sesuai dengan pendapat Jordan E Ayan (2002) yang menyatakan bahwa dalam proses pembelajaran, cara dan gaya baru yang disajikan kepada siswa, pada umumnya menimbulkan rasa ingin tahu siswa. Rasa ingin tahu mendorong seseorang untuk menyelidiki bidang baru atau mencari cara mengerjakan sesuatu dengan lebih baik.

Penerapan model pembelajaran berbasis masalah juga dapat mengoptimalkan pengalaman belajar, seperti pengalaman mengamati, mencatat data, dan melakukan kajian literatur, dan mengkomunikasikan pengetahuan. Keadaan ini mendorong aksi dan refleksi pada siswa, untuk segera tanggap dengan situasi pembelajaran yang baru. Pembelajaran yang melibatkan seluruh indera akan lebih bermakna dibandingkan dengan satu indera saja.

\section{KESIMPULAN DAN SARAN Kesimpulan}

Berdasarkan hasil penelitian dan pembahasan dapat disimpulkan bahwa: Pembelajaran Biologi dengan model pembelajaran berbasis masalah dapat meningkatkan keterampilan berpikir kritis siswa kelas $\mathrm{X}_{4}$ SMA Negeri 2 Metro.

\section{Saran}

Dari hasil penelitian ini dapat diberikan saran, yaitu 1) Pembelajaran Biologi dengan model pembelajaran berbasis masalah dapat meningkatkan keterampilan berpikir kritis siswa sehingga disarankan agar guru-guru dapat menerapkan dan mengembangkannya sesuai dengan situasi dan kondisi di sekolah; 2) Dalam merancang model pembelajaran Biologi dengan model pembelajaran berbasis masalah pada mata pelajaran Biologi, disarankan agar materi, alat, dan bahan yang dijadikan sebagai pendukung KBM faktual, aktual mudah didapat, murah, dan ada di lingkungan siswa atau sekolah sehingga pembelajaran menjadi konkrit, aplikatif, dan kontekstual; dan 3) Disarankan kepada guru-guru pada umumnya, dan guru sains khususnya, agar terus melakukan inovasi model pembelajaran sehingga dapat meningkatkan kualitas proses dan hasil belajar.

\section{DAFTAR RUJUKAN}

Ali, Muhammad H. 2000. Guru Dalam Proses Belajar Mengajar. Cetakan ke-10. Bandung: PT Sinar Baru Algensindo

Arnyana, Ida Bagus Putu. 2004. Pengembangan Perangkat Model Belajar Berdasarkan Masalah Dipandu Strategi Kooperatif Serta Pengaruh Implementasinya Terhadap Kemampuan Berpikir Kritis dan Hasil Belajar Siswa Sekolah Menengah Atas pada Pelajaran Ekosistem. (Disertasi). Universitas Negeri Malang. PPS Program Studi Pendidikan Biologi

Ayan, Jordan E. 2002. Bengkel Kreativitas: $\quad 10 \quad$ Cara Menemukan Ide-ide Pamungkas. 
Penerjemah Ibnu Setiawan. Hassoubah, Zaleha Izhab. 2007. Aha!: 10 Ways to Free Your Mengasah Pikiran Kreatif dan Creative Spirit and Find Your Kritis: Disertai Ilustrasi dan Great Ideas Bibliografi. 1997. Latihan. Terjemahan Bambang Bandung: Kaifa

BSNP. 2006. Standar Kompetensi dan Kompetensi Dasar Untuk SMA/MA Kurikulum Tingkat Satuan Pendidikan Jenjang Pendidikan Dasar dan Menengah. Jakarta

Costa, Arthur L. (ed). 1988. Developing Minds: A Resource Book For Teaching Thinking. Virginia: ASCD

Suryadi. Developing Creative \& Critical Thinking Skills: A Handbook for Students. 2002. Bandung: Nuansa

Muhfahroyin, 2009. Memberdayakan Kemampuan Berpikir Kritis.(Online). (http://www.berpikirkritisblogspot.com). diakses Oktober 2011.

Depdiknas. 2002. Kurikulum Berbasis Kompetensi. Jakarta: Puskur, Balitbang Depdiknas 